\title{
The demographic characteristics and economic activity patterns of carers over 50: evidence from the English Longitudinal Study of Ageing
}

Athina Vlachantoni

University of Southampton

\begin{abstract}
Studies on informal care provision have often focused on the provision of care for persons with a long term physical or mental ill-health or disability, or problems related to old age. However, the provision of care and support more broadly, for example in the form of childcare for grandchildren, can also impact on various aspects of a carer's life, such as their employment (if under the state retirement age), lifetime earnings and, by extension, pension income in later life. This article uses data from Wave 3 of the English Longitudinal Study of Ageing (ELSA) to explore the demographic characteristics, caring patterns, health status and economic activity patterns of carers aged over $\mathbf{5 0}$ in England. The results suggest that the nature of care provision differs across age groups, and that caring can be quite a different experience for older men and women. This article also sheds light on the characteristics of 'round-the-clock' carers, a relatively under-researched group which makes up just over one fifth of all carers aged 50 and over.
\end{abstract}




\section{Contents}

The demographic characteristics and economic activity patterns of carers over 50 : evidence from the English Longitudinal Study of Ageing .54

Abstract.

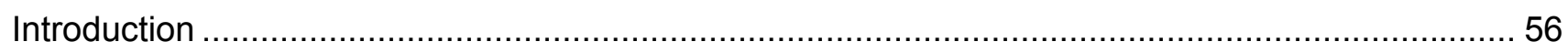

Data and methods.

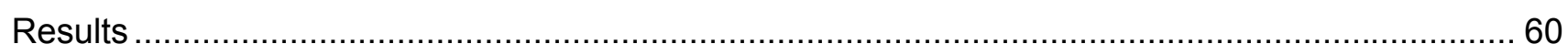

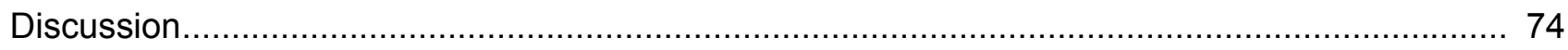

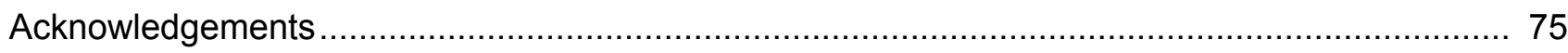

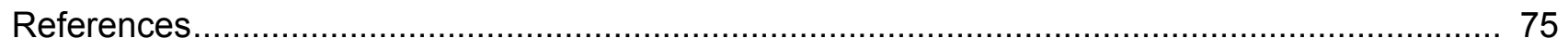




\section{Introduction}

The activity of caring, whether for one's family, friends or neighbours, has always been part of the human life course. With rapid population ageing affecting both those who receive and those who provide care, researching patterns of informal care provision assumes increasing policy relevance. The 2001 Census showed that about 10 per cent of the UK's population (or 5,884,450 persons) provided unpaid care to "family members, friends, neighbours or others because of long term physical or mental ill-health or disability or problems relating to old age", with a similar proportion for the English population (9.9 per cent of total population) ${ }^{1}$. From the 2000 General Household Survey (GHS) we know that married or cohabiting adults are more likely to be carers than those who are single, or were previously married, and that over one in four carers spends at least 20 hours per week on their caring responsibilities ${ }^{2}$. The 2000 GHS also showed that 18 per cent of women compared to 14 per cent of men were carers, and studies of informal care provision have often highlighted the impact of such gender differences on women's employment, earnings, and by extension, pension entitlements ${ }^{3}{ }^{4}$.

Studies on informal care provision have often focused on the provision of care towards long term, sick or elderly persons, and often on carers aged between 35-64, who constituted approximately 65 per cent of all informal carers in $2001^{1}$. However, the provision of care can also take other forms, for example, providing childcare for one's grandchild or supporting one's neighbour in performing household tasks. All forms of care provision can impact on the employment patterns of carers prior to retirement, and on the income and pension income of carers more generally, as well as on the quality of life of the person receiving care. In addition, all forms of care provision have implications for the design of social policy supporting both carers and those receiving care. The English Longitudinal Study of Ageing (ELSA) provides a unique opportunity to explore the provision of care, not only towards long term sick, disabled or elderly persons, but also towards other persons, younger or older, who require different kinds and levels of support and care. With evidence of a projected rise in the older part of the population ${ }^{5}$ and a rising demand for informal care $^{6}$, understanding the nature of informal care provision can lead to better understanding of its impact on the carers' socio-economic status across the life course.

The ELSA dataset also allows exploration of the nature of caring, particularly by those aged 50 and over, an age group that is relatively under-researched in existing literature ${ }^{7}$. We know from the 2001 Census that there were approximately 1.24 million men and 1.56 million women over the age of 50 providing unpaid care to sick/disabled persons and that half of these were concentrated among the 'younger old', that is those aged between $50-59^{19}$. Gender differences again permeate these patterns, with women being more likely to be carers than men, except among older ages, and women being more likely to care for persons outside their household ${ }^{10}{ }^{11}$. Looking at caring in a broader sense, and not only towards long-term sick, disabled or elderly persons, results from the first wave of the ELSA have shown that the majority (56 per cent) of carers aged 50 and over provided up to 19 hours of care per week, about a quarter provided 50 hours of care or more every week, and just over one fifth of all older carers provide care round-the-clock (168 hours per week $)^{12}$. The focus of this article is on persons aged 50 and over as providers rather than receivers of care, and this serves two purposes. First, against evidence of greater role juggling in mid and late life ${ }^{13}$, the analysis sheds light on the combination of care provision among the 'younger old' aged between 50 and the state retirement age, some of whom may still be engaged in paid work. 
Secondly, the analysis contributes to a growing body of literature, aimed at understanding and recognising the role and contribution of older people as carers ${ }^{8} 14$.

\section{Data and methods}

The ELSA is a study of people aged 50 and over and their younger partners, living in private households in England. The sample has been drawn from households which previously responded to the Health Survey for England (HSE) between 1998 and 2006. The HSE is an annual crosssectional household survey which collects a wide range of health data and biometric measures. Each HSE sample is drawn using a two-stage sampling strategy, which involves a selection based on postcodes selected from the Postcode Address File (PAF) and a random selection of households from a fixed number of addresses covering each postcode sector. As a result, the HSE is nationally representative of private households.

There are two main disadvantages in using ELSA data. Firstly, there is the potential loss of representativeness before the ELSA data are drawn from HSE data, due to non-response to HSE, refusal to be re-contacted and attrition between HSE and ELSA. Secondly, as with many national surveys, individuals living in institutions such as residential and nursing homes, are excluded from the ELSA. However, the ELSA aims to look at the circumstances surrounding the move into an institution, and the refreshment of the sample at each wave and the use of weighting partly address the potential loss of representativeness ${ }^{15}$.

The analysis presented in this article focuses primarily on Wave 3 (2006) of the ELSA, which at the time of going to print was the most recent wave including a weighting variable. This dataset has a total of 10,513 respondents, of whom 9,771 provided valid responses. These included 7,535 core members (individuals aged 50 and over), 91 core partners, 312 younger partners (partners of core members who were up to 49 years old), 74 'new' partners (who had joined the household since the HSE interview and were found in previous waves) and 26 new partners (who had joined the household since the HSE interview and were found in Wave 3). The initial ELSA sample was refreshed during Waves 2, 3 and 4, in order to make it representative of the youngest people who had aged since each previous wave. The refreshment sample in Wave 3 contains 1,275 core members, 142 older partners, 295 younger partners and 21 new partners (found in Wave 3$)^{15}$.

Table 1 uses data from Waves 2, 3 and 4 of the ELSA to show the proportion of different types of carers between 2004-08. Wave 2 (2004) includes a total of 9,432 respondents, and Wave 4 (Phase 1, 2008) includes 10,860 respondents. Wave 1 has been omitted from this comparative table because carers were identified in a different way in this wave, resulting in a significantly different sample population. The article is based on bivariate and multivariate analysis using SPSS. The definitions of key variables used in the analysis in this article are below.

\section{Definition of carers}

In Waves 2, 3 and 4 of the ELSA dataset carers were identified in two steps. First, the total sample was asked the following question:

'Did you do any of the following activities during last month?' 
Those who included 'caring' in their response to the above question were then asked the following question:

'Did you look after anyone in the last week (including your partner or other people

in your household)? By 'look after' we mean the active provision of care.'

The sequence in which the two questions were asked has implications both for the total number of carers identified in the sample and for the types of carers identified. Figure 1 shows a graphic representation of how carers are identified in Wave 3 . The first question yielded a total of 1,271 respondents, who had provided care during the previous month, while the second question reduced the carers' sample to 1,000 persons, who had provided care during both the previous month and during the previous week. Both questions and categories of carers have been taken into account for the analysis in this article. The first part of the article includes a description of the demographic characteristics of carers from both categories (ie. who either cared for another person during the previous week and/or who mentioned caring as part of their activities during the previous month), in order to provide a full picture of caregivers in the dataset. The remainder of the article (Tables 4-12 and Figures 2-4) uses data on those who provided care during the previous week as the unit of analysis. This is because the detailed data on the nature of the activity of caring is only available for this subgroup of carers.

\section{Figure 1 Questions on caring in ELSA, Wave 3}

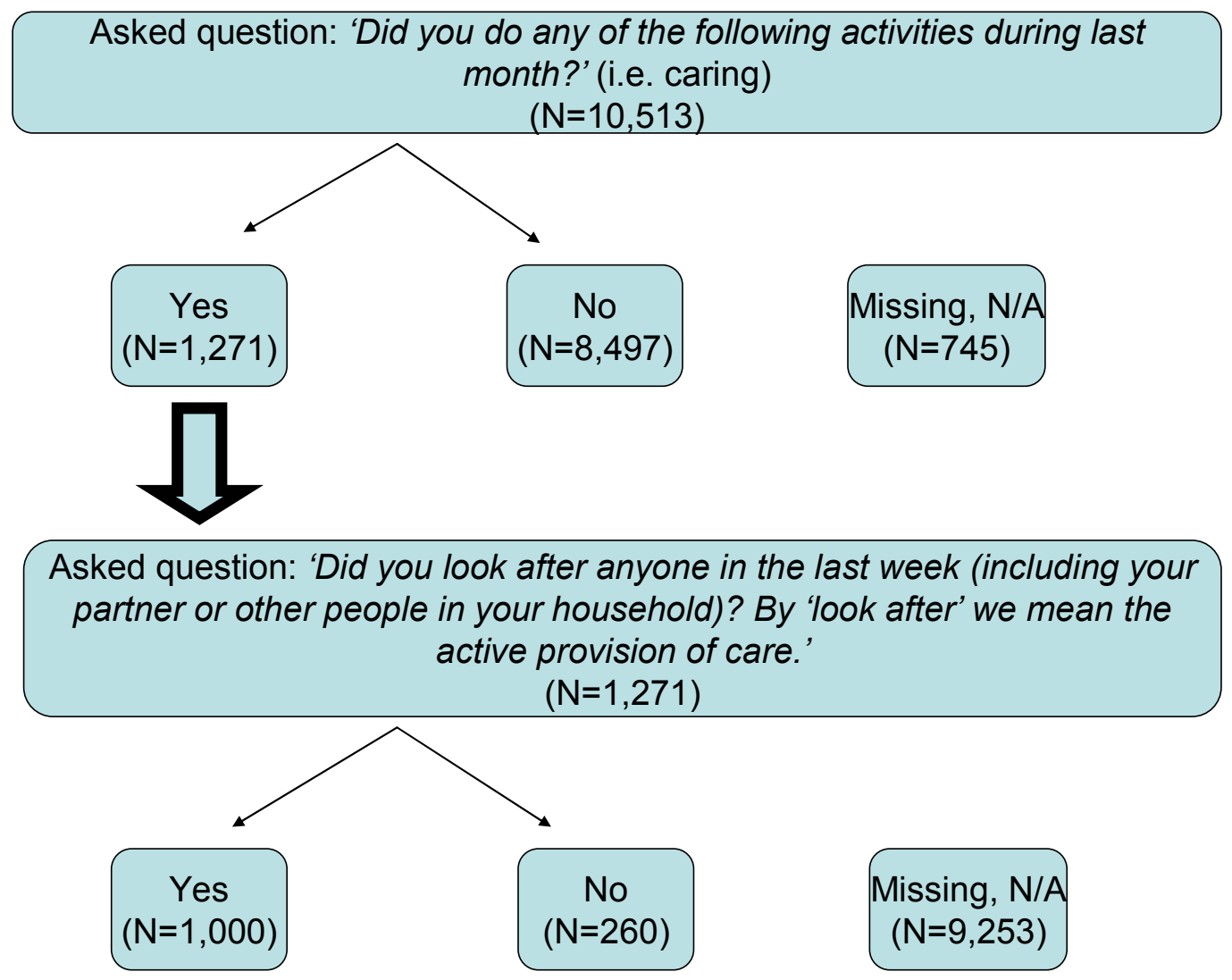




\section{Definition of care intensity}

The duration of care provided by older people is measured by the number of hours of care provided per week, ranging from one hour to 168 hours, which represents care provided all the time, or 'round-the-clock'. The majority of carers provided up to 19 hours of care per week, about one fifth provided round-the-clock care and smaller proportions of carers provided care for 20-167 hours per week. The continuous variable has been recoded into four categories of care intensity: 1-19 hours, 20-49 hours, 50-167 hours and round-the-clock care (168 hours per week). This is in order to be consistent with earlier analysis of the ELSA dataset ${ }^{12}$, and to be able to explore the group of round-the-clock carers in greater detail.

\section{Relationship to the person receiving care}

The ELSA questionnaire asks those who provided care during the previous week to define their relationship to the person receiving care. About one tenth of all carers had looked after more than one person. For this category, co-residence with the person receiving care refers to the main person they looked after, while the total number of hours of care provided includes care for all the persons they looked after. In recognition of the different nature of care provided to different persons, and where larger sample sizes were required, the analysis used a recoded variable which distinguishes between four categories. The first category includes those caring for one's spouse/ partner only, the majority of whom are co-residing with the person they care for. The second category comprises those caring for a parent or a parent-in-law, and in the third category are those caring for a relative, or a friend/neighbour. Finally, the fourth category includes those caring for a child or a grandchild, with the majority of carers in this category caring for a grandchild (Figure 2). Although caring for a child in later life may often resemble care for an adult more closely, while care for a grandchild is more likely to be childcare, these two categories of carers are sufficiently different from all other types of carers to be amalgamated for part of the analysis.

\section{Definition of marital status}

The 'married' category includes those who are currently married or in a civil partnership (first or subsequent marriage/civil partnership), although the vast majority of this category are married individuals. The dataset does not provide direct information about de facto marital status, which could include a partnership and/or cohabitation outside a legally recognised union.

\section{Definition of health status}

Wave 3 of the ELSA includes two questions which are used in this article to explore the health status of carers: self-reported general health status and the report of a limiting longstanding illness. The question on self-reported general health status allowed for five responses (very good, good, fair, bad, very bad), which have been recoded into the following three categories:

$\begin{array}{ll}\text { Very good/good } & =\text { good } \\ \text { Fair } & =\text { fair } \\ \text { Bad/very bad } & =\text { poor }\end{array}$




\section{Definition of economic activity:}

The economic activity variable, across all four waves, is derived from the question:

'Which one of these would you say best describes your current situation?'

Economic activity is analysed using five categories (retired/semi-retired; employed/self-employed; unemployed; permanently sick/disabled; and looking after home/family), before distinguishing between those engaged in some kind of 'paid' economic activity (employed, self-employed and unemployed) and those who are not (retired, semi-retired, permanently sick/disabled and looking after home/family).

\section{Results}

The results are presented in four parts. The first part explores the demographic characteristics of older carers (for example, age, sex, marital status); the second part explores the nature of the caring activity in greater detail (for example, who they care for, how many hours of care per week, etc); the third part explores the association between the caring activity on one hand, and the carers' health status and their patterns of economic activity on the other; finally, the fourth part investigates the predictors of being a round-the-clock carer for men and women. Part I includes all carers while Parts II-IV focus only on those who report caring for someone in the last week.

\section{Who cares?}

Table 1 shows the proportion of those aged 50 and over who provided care between 2004-08, using both definitions used in the ELSA questionnaire to identify carers, ie. those who cared during the previous week and those who cared during the previous month. The table shows a stable proportion of men who provided care during the previous week between 2004-06 (7.8 per cent and 7.9 per cent), and a decline reflected in the 2008 unweighted data (6.7 per cent).

\section{Table 1 Carers and non-carers, by sex, 2004-08}

\begin{tabular}{lrrr}
\hline & $\mathbf{2 0 0 4}^{\mathbf{a}}$ & $\mathbf{2 0 0 6}^{\mathbf{b}}$ & $\mathbf{2 0 0 8}^{\mathbf{c}}$ \\
\hline Men & & & \\
Cared last week & 7.8 & 7.9 & 6.7 \\
Cared last month & 2.2 & 2.0 & 2.4 \\
Did not provide care & 90.0 & 90.0 & 90.9 \\
Number in analysis & 4,126 & 4,291 & 4,832 \\
& & & \\
Women & 13.1 & 12.3 & 11.0 \\
Cared last week & 3.6 & 2.9 & 3.9 \\
Cared last month & 83.3 & 84.8 & 85,1 \\
Did not provide care & 5,306 & 5,466 & 5,997 \\
Number in analysis & & & \\
\hline
\end{tabular}

a: $x 2=82.163, d f=2, p<0.001 ; \quad b: x 2=52.545, d f=2, p<0.001$; C: $x 2=82.168, d f=2, p<0.001$

2004-06: Weighted percentages and unweighted frequencies. 2008: Unweighted percentages and frequencies.

Source: ELSA, Waves 2-4 
For men who provided care during the previous month, and for women who provided care during the previous week or month, the 2004-06 data show a small decline, while the 2008 unweighted data show a small increase for men and women who provided care during the previous month. The proportion of the sample who did not provide care has remained constant around 90 per cent for men and around 84 per cent for women between 2004-08. Finally, women are more likely than men to have provided care across the three waves, whether during the previous week or during the previous month.

Patterns of care provision vary for different age groups, but also in different ways for men and women. In 2006 the proportion of all carers in the population aged 50 and over decreased in line with increasing age. Table 2 shows that just over 15 per cent of those aged 50-59 had provided care during the previous week or month, compared to 13 per cent of those aged 60-69, 12 per cent of those aged 70-79 and almost six per cent of those aged 80 and over. Women were more likely to provide care than men in every age group except among the oldest (those aged 80 and over), where men were more likely to be carers.

\section{Table 2 Care status by age group and sex, 2006}

\begin{tabular}{|c|c|c|c|c|}
\hline & $\begin{array}{l}50-59 \\
\text { years }\end{array}$ & $\begin{array}{l}60-69 \\
\text { years }\end{array}$ & $\begin{array}{l}70-79 \\
\text { years }\end{array}$ & $\begin{array}{l}80 \text { years } \\
\text { and over }\end{array}$ \\
\hline \multicolumn{5}{|l|}{$\operatorname{Men}^{\mathrm{a}}$} \\
\hline Cared last week & 7.4 & 7.8 & 9.3 & 7.8 \\
\hline Cared last month & 2.9 & 1.6 & 1.9 & {$[0.7]$} \\
\hline Did not provide care & 89.7 & 90.6 & 88.8 & 91.5 \\
\hline Number in analysis & 1,542 & 1,279 & 929 & 453 \\
\hline \multicolumn{5}{|l|}{ Women $^{\mathrm{b}}$} \\
\hline Cared last week & 16.6 & 13.9 & 10.0 & 3.2 \\
\hline Cared last month & 3.8 & 3.4 & 2.1 & [1.1] \\
\hline Did not provide care & 79.6 & 82.7 & 88.0 & 95.7 \\
\hline Number in analysis & 1,887 & 1,423 & 1,134 & 680 \\
\hline \multicolumn{5}{|l|}{ All carers $^{c}$} \\
\hline Cared last week & 12.1 & 10.9 & 9.6 & 4.9 \\
\hline Cared last month & 3.3 & 2.6 & 1.9 & 1.0 \\
\hline Did not provide care & 84.6 & 86.6 & 88.5 & 94.1 \\
\hline Number in analysis & 3,429 & 2,702 & 2,063 & 1,133 \\
\hline$a: x 2=12.623, d f=6, p<0.010$ & \multicolumn{3}{|c|}{$b: x 2=109.311, d f=6, p<0.001$} & $c: x 2=73.371, d f=6, p<0.001$ \\
\hline \multicolumn{5}{|c|}{ Note: Percentages in brackets are based on cell counts below 10.} \\
\hline \multicolumn{5}{|c|}{ Source: ELSA, Wave 3} \\
\hline \multicolumn{5}{|c|}{$\begin{array}{l}\text { The association between being married and providing care was evident in the ELSA dataset, but } \\
\text { so were gender differences in this respect. Men who provided care were more likely to be married } \\
\text { than women who provided care ( } 85 \text { per cent of all male carers and } 77 \text { per cent of all female carers } \\
\text { were married ( } p<0.001) \text { ). Women were twice as likely as men to provide care, regardless of their } \\
\text { marital status (Table } 3) \text {. The only exceptions were widows and widowers, who were almost equally } \\
\text { likely to be carers. The results show that women are more likely than men to provide care during } \\
\text { the previous month or week. They are more likely to provide care across different age groups, }\end{array}$} \\
\hline
\end{tabular}


except over the age of 80 , and are more likely to provide care regardless of their marital status, (except for widows).

\section{Table 3 Care status by marital status and sex, 2006}

\begin{tabular}{|c|c|c|c|c|}
\hline & $\begin{array}{l}\text { Single/never } \\
\text { married }\end{array}$ & $\begin{array}{l}\text { Married/civil } \\
\text { partnership }\end{array}$ & $\begin{array}{l}\text { Divorced/ } \\
\text { seprarated }\end{array}$ & Widowed \\
\hline \multicolumn{5}{|l|}{ Men $^{\mathrm{a}}$} \\
\hline Cared last week & 4.6 & 9.1 & 5.2 & 3.9 \\
\hline Cared last month & [1] & 2.1 & 2.2 & [2] \\
\hline Did not provide care & 94.4 & 88.8 & 92.6 & 94.1 \\
\hline Number in analysis & 282 & 3,216 & 412 & 381 \\
\hline \multicolumn{5}{|l|}{ Women $^{\mathrm{b}}$} \\
\hline Cared last week & 9.7 & 16.2 & 10.2 & 4.4 \\
\hline Cared last month & [2.1] & 3.2 & 3.7 & 2.0 \\
\hline Did not provide care & 88.2 & 80.6 & 86.1 & 93.6 \\
\hline Number in analysis & 291 & 3,310 & 674 & 1,191 \\
\hline
\end{tabular}

a: $x 2=24.012, d f=6, p<0.001 ; \quad b: x 2=113.012, d f=6, p<0.001$

Note: Percentages in brackets are based on cell counts below 10.

Source: ELSA, Wave 3

These results confirm a strong relationship between caring and gender in later life, which has been found elsewhere. For example, Glaser and Grundy $(2002)^{11}$ found that women are more likely to provide care, especially outside the household, among those aged 55-69, while Arber and Ginn $(1995)^{10}$ also showed that women are more likely than men to care for someone outside the household. Dahlberg et al $(2007)^{8}$ found that men aged 70 and over are more likely to be carers than women and Del Bono et al (2009) ${ }^{16}$ attributed men's greater likelihood to provide care at older ages to gender differences in marital status at those ages, that is, a greater likelihood for older men to have a partner to care for. Finally, Young et al (2006) ${ }^{17}$ studied couples of which one of the spouses suffered from a LLSI, and found that women were slightly more likely to provide care than men.

Researching the caring activity in greater detail reveals even more differences in the ways men and women experience care provision in later life. The remainder of the analysis focuses on those who provided care during the previous week.

\section{The nature of the caring activity}

This section explores the nature of the caring activity, including the relationship to the person receiving care, the number of hours of care provided per week and the prevalence of co-residence with the person receiving care. Figure 2 shows that a greater proportion of female carers than male carers looked after parents, grandchildren, friends/neighbours, children, other relatives or parents-in-law, while men were more likely to be caring for their spouse/partner. For example, about one third of women cared for a parent compared to 23 per cent of men, and about 17 per cent of women cared for a grandchild compared to nine per cent of men, but 43.5 per cent of men compared to 26 per cent of women cared for their spouse/partner. In Figure 2 the total proportion of women who looked after different categories of care recipients adds up to more than 100 per 
cent, because women are more likely than men to be juggling multiple caring roles. Figure 3 shows that 72 per cent of women compared to 85 per cent of men cared for one person only, while 16 per cent of women compared to eight per cent cared for two persons, five per cent of women compared to four per cent of men cared for three persons, and three per cent of all female carers looked after four persons. This adds a clear gender dimension to the evidence showing multiple role performance in mid and late life ${ }^{13}$, at least in so far as caring over the age of 50 is concerned.

\section{Figure 2 Relationship to the person receiving care, by sex, 2006}

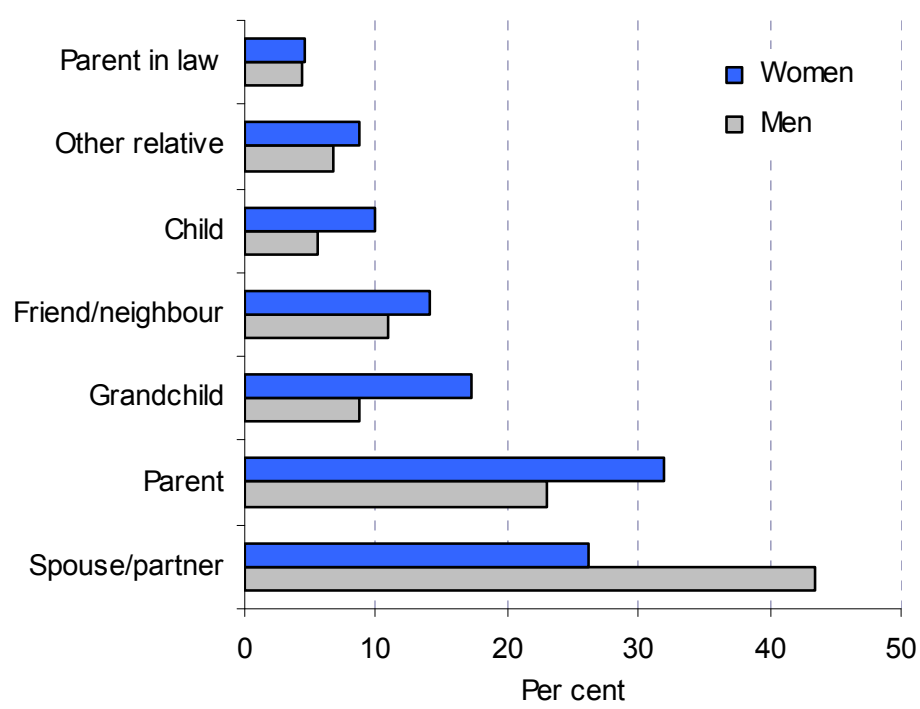

$\mathrm{x} 2=44.334, \mathrm{df}=6, \mathrm{p}<0.001$.

Weighted percentages. Male carers $(\mathrm{N}=334)$; Female carers $(\mathrm{N}=666)$

Note: Percentages add up to more than 100 per cent as some people care for more than one individual.

Source: ELSA, Wave 3

\section{Figure 3 Number of persons receiving care, by sex, 2006}

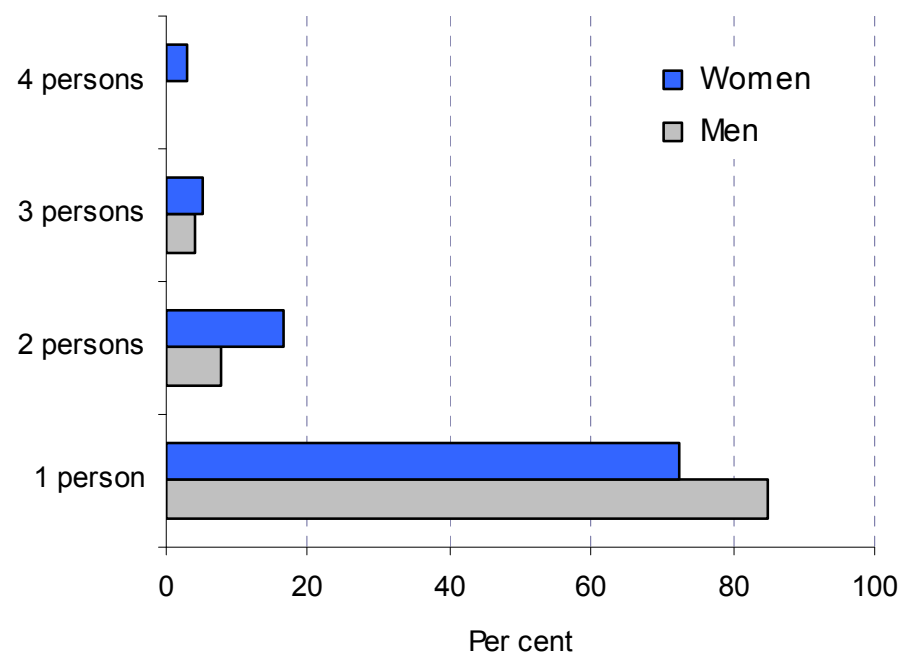

Men: $\mathrm{x} 2=4057.000, \mathrm{df}=20, \mathrm{p}<0.001$.

Women: $x 2=4604.000, d f=42, p<0.001$

Source: ELSA, Wave 3 
Table 4 suggests that the relationship of the carer with the person they care for changes for different age groups. There are significant differences in the way these changes are manifested among male and female carers. 'Younger old' carers (50-59) were more likely to care for parents/ parents-in-law or for children/grandchildren, while 'older old' carers (80 and over) were more likely to care for their spouse/partner or for other relatives/friends/neighbours. Just over half of all carers aged 50-59 cared for a parent/parent-in-law, and one fifth of this age group cared for a child/ grandchild. The older the carer, the more likely they were to be looking after their spouse/partner, compared to the combined categories of caring for a parent/parent-in-law or a child/grandchild. In the oldest age group almost two thirds of carers aged 80 and over looked after their spouse/ partner, and almost one quarter of carers in this age group looked after another relative/friend/ neighbour. At the same time the changes between different age groups in the relationship with the person receiving care happen in different ways for men and women. Almost one quarter of male carers aged 50-59 looked after their spouse/partner, compared to just over one tenth of female carers in that age group. Women aged 50-59 and 60-69 were more likely than men in these age groups to care for a child/grandchild, while men in all age groups were more likely than women to care for their spouse/partner. When care intensity it taken into account, the differences between male and female carers become even more striking.

\section{Table 4 Relationship to person receiving care by age and sex, 2006}

\begin{tabular}{|c|c|c|c|c|}
\hline & $\begin{array}{l}50-59 \\
\text { years }\end{array}$ & $\begin{array}{l}60-69 \\
\text { years }\end{array}$ & $\begin{array}{l}70-79 \\
\text { years }\end{array}$ & $\begin{array}{l}80 \text { years } \\
\text { and over }\end{array}$ \\
\hline \multicolumn{5}{|l|}{ All carers ${ }^{a}$} \\
\hline Cared for spouse/partner & 14.8 & 31.4 & 42.9 & 61.8 \\
\hline Cared for parent/parent-in-law & 50.7 & 26.8 & 7.9 & {$[0.1]$} \\
\hline Cared for other rel./friend/neighbour & 14.6 & 20.0 & 33.9 & 23.6 \\
\hline Cared for child/grandchild & 19.9 & 21.8 & 15.3 & [14.5] \\
\hline Number in analysis & 406 & 290 & 194 & 53 \\
\hline \multicolumn{5}{|l|}{ Men $^{\mathbf{b}}$} \\
\hline Cared for spouse/partner & 24.1 & 42.7 & 58.4 & 65.6 \\
\hline Cared for parent/parent-in-law & 45.4 & 31.3 & [3.9] & - \\
\hline Cared for other rel./friend/neighbour & 15.7 & 12.5 & 26.0 & [21.9] \\
\hline Cared for child/grandchild & 14.8 & 13.5 & 11.7 & [12.5] \\
\hline Number in analysis & 112 & 98 & 81 & 31 \\
\hline \multicolumn{5}{|l|}{ Women ${ }^{c}$} \\
\hline Cared for spouse/partner & 10.8 & 25.5 & 31.3 & 56.5 \\
\hline Cared for parent/parent-in-law & 53.0 & 24.5 & 11.1 & - \\
\hline Cared for other rel./friend/neighbour & 14.1 & 23.9 & 40.4 & [26.1] \\
\hline Cared for child/grandchild & 22.1 & 26.1 & 17.2 & {$[17.4]$} \\
\hline Number in analysis & 294 & 192 & 113 & 22 \\
\hline
\end{tabular}

$a: x^{2}=175.975, d f=9, p<0.001 ; \quad b: x 2=61.637, d f=9, p<0.001$;

C: $x 2=111.994, d f=9, p<0.001$

Note: Percentages in brackets are based on cell counts below 10.

Source: ELSA, Wave 3 


\section{Figure 4 Care intensity by sex, 2006}

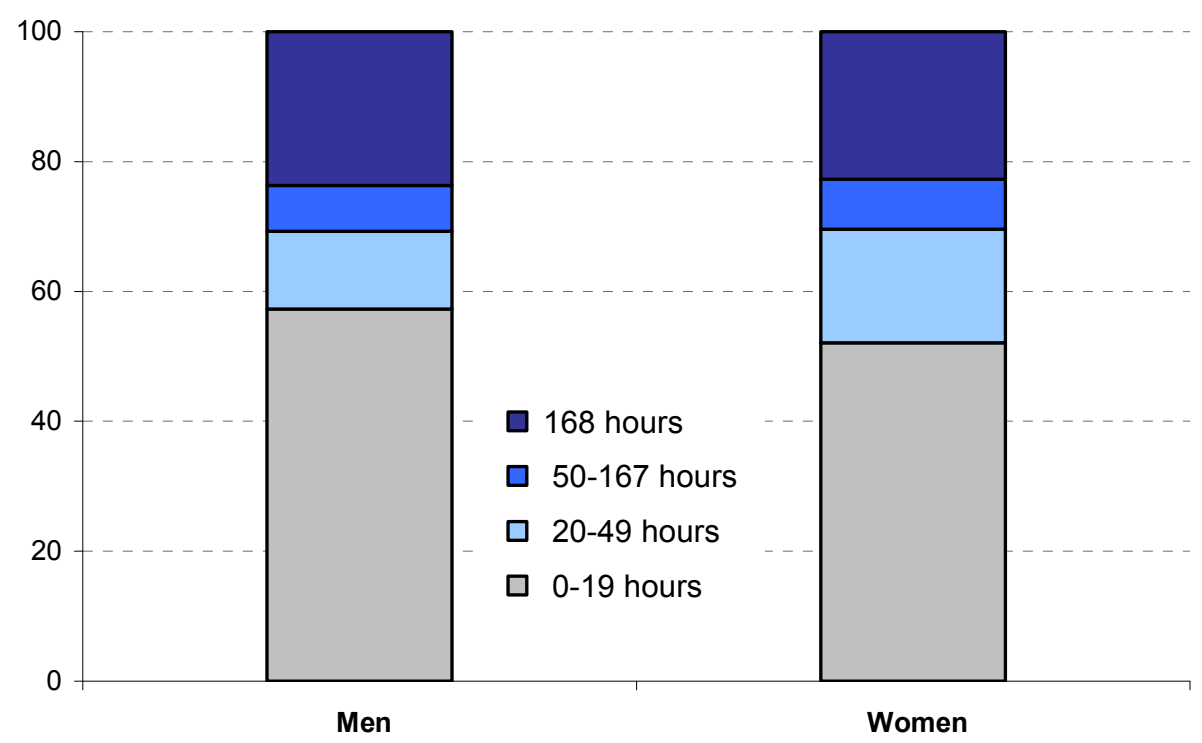

2006: $\mathrm{x} 2=5.193, \mathrm{df}=3, \mathrm{p}=0.158$

Source: ELSA, Wave 3

When considering the intensity of care provided, the ELSA data show that about 56 per cent of all carers provided up to 19 hours of care per week, about 15 per cent provided between 20-49 hours of care, almost eight per cent provided between 50-167 hours, and finally just over one fifth provided round-the-clock care. However, there are certain gender differences as Figure 4 shows. Women were less likely than men to provide up to 19 hours of care, and more likely than men to provide between 20-49 hours of care. Men and women over the age of 50 were almost as likely to provide between 50-167 hours of care and to be round-the-clock carers.

We already know that for women the 'younger old' are more likely to be carers than the 'older old' (Table 2), but age appears to be also associated with the number of hours of care provided, with the majority of less intense carers being younger old, but more than half of round-the-clock carers are aged 65 and over (Table 5). These patterns were broadly similar for men and women, with a couple of exceptions; for example, among those caring between 20-49 hours per week, 55 per cent of men compared to 72 per cent of women were aged 50-64, and among round-the-clock carers, one third of men compared to one half of women were aged 50-64.

Analysing care intensity alongside the relationship with the person receiving care provides further insight in the gendered nature of care giving in older ages. Table 6 shows that among those caring for up to 19 hours per week, about two fifths of both men and women cared for a parent/parent-inlaw, while among those caring for 20-49 hours per week, two fifths of women looked after a child/grandchild and two the same proportion of men looked after their spouse/partner.

Gender becomes a crucial differentiating factor when it comes to round-the-clock care, as although the majority of all round-the-clock carers provided care to their spouse/partner, this was more the case for men than for women (88 per cent of men compared to 57 per cent of women). Female round-the-clock carers were much more likely to look after a child/grandchild (22 per cent). 


\section{Table 5 Care intensity by age group, 2006}

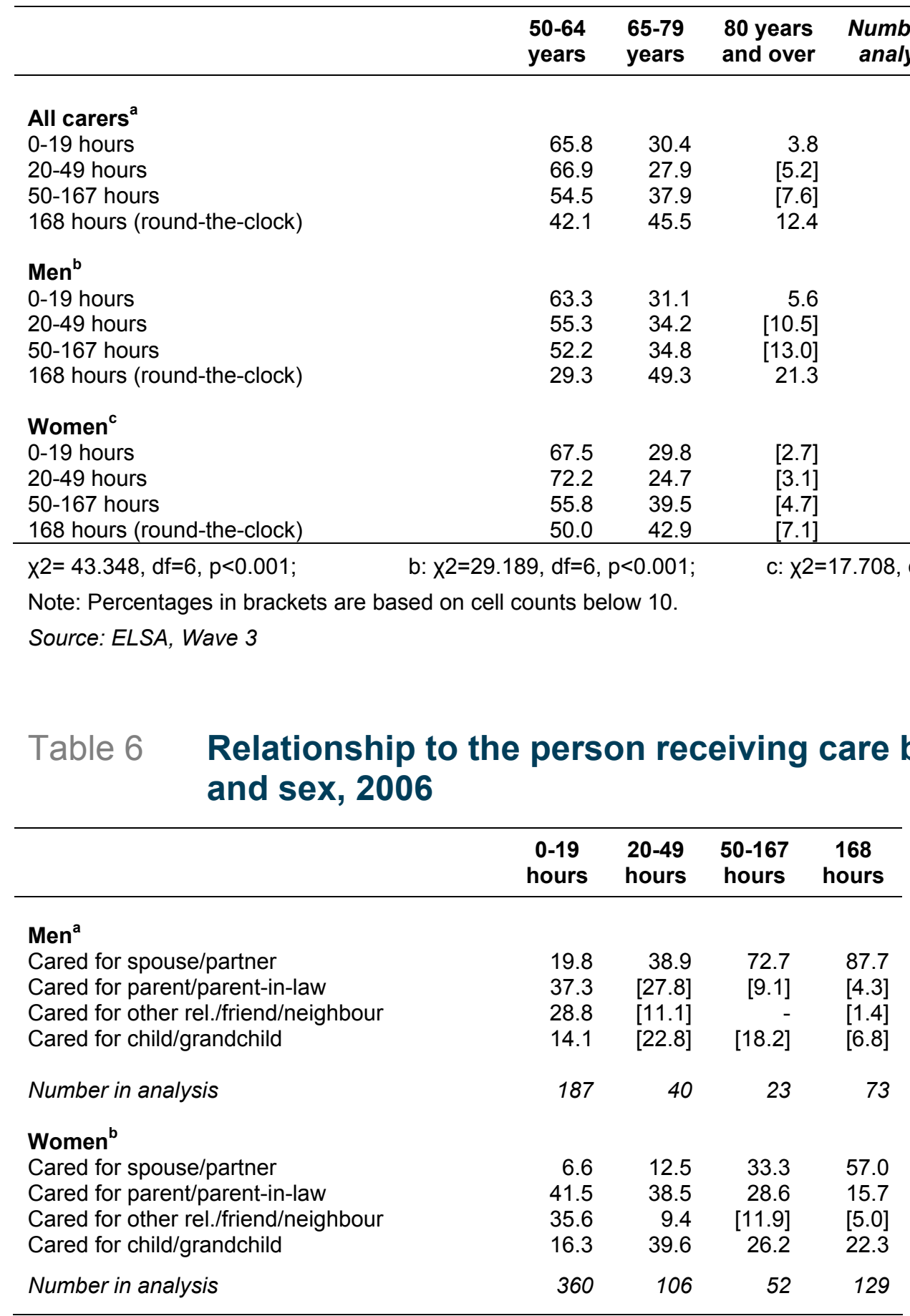

a: $x 2=118.694, d f=9, p<0.001 ; \quad b: x 2=194.323, d f=9, p<0.001$

Note: Percentages in brackets are based on cell counts below 10.

Source: ELSA, Wave 3

The caring experience, including its intensity, precise tasks as well as the extent to which it is supported by the welfare state, can be different depending on whether the carer lives with the person care is provided for. The ELSA data show that about 40 per cent of carers aged 50 and over lived with the person they cared for, and that the prevalence of co-residence increases in line with a rise in care intensity. For example, less than one fifth of those caring for up to 19 hours lived 
with the person they cared for, compared to one third of those caring for 20-49 hours, two thirds of those caring for 50-167 hours and the vast majority of round-the-clock carers.

Co-residence also varied according to the relationship with the person receiving care. Table 7 shows the proportion of carers who lived with the person receiving care, based on their relationship to that person. Perhaps not surprisingly, almost all of those caring for their spouse/partner lived with them, compared to about one third of those caring for a child/grandchild, one fifth of those caring for apparent/ parent-in-law and about nine per cent of those caring for another relative, friend or neighbour. There were almost no gender differences among carers in this respect, except for women caring for a child/grandchild, who were far more likely than men to live with them (33 per cent compared to 26 per cent).

\section{Table 7 Relationship to person receiving care, by co-residence, 2006}

\begin{tabular}{|c|c|c|c|}
\hline & $\begin{array}{c}\text { Lived } \\
\text { with them }\end{array}$ & $\begin{array}{l}\text { Lived } \\
\text { apart }\end{array}$ & $\begin{array}{c}\text { Number in } \\
\text { analysis }\end{array}$ \\
\hline \multicolumn{4}{|l|}{ All carers ${ }^{a}$} \\
\hline Cared for spouse/partner & 99.2 & {$[0.8]$} & 260 \\
\hline Cared for parent/parent-in-law & 19.3 & 80.7 & 317 \\
\hline Cared for other rel./friend/neighbour & 9.8 & 90.2 & 204 \\
\hline Cared for child/grandchild & 31.3 & 68.7 & 191 \\
\hline \multicolumn{4}{|l|}{ Men ${ }^{b}$} \\
\hline Cared for spouse/partner & 99.2 & {$[0.8]$} & 137 \\
\hline Cared for parent/parent-in-law & 20.5 & 79.5 & 88 \\
\hline Cared for other rel./friend/neighbour & [7.5] & 92.5 & 56 \\
\hline Cared for child/grandchild & 26.2 & 73.8 & 42 \\
\hline \multicolumn{4}{|l|}{ Women ${ }^{c}$} \\
\hline Cared for spouse/partner & 99.2 & {$[0.8]$} & 123 \\
\hline Cared for parent/parent-in-law & 19.1 & 80.9 & 229 \\
\hline Cared for other rel./friend/neighbour & 10.7 & 89.3 & 148 \\
\hline Cared for child/grandchild & 33.1 & 66.9 & 149 \\
\hline
\end{tabular}
a: $x 2=473.266, d f=3, p<0.001$;
b: $x 2=205.374, d f=3, p<0.001$;
c: $x 2=256.196, d f=3, p<0.001$

Notes: Percentages in brackets are based on cell counts below 10 .

Source: ELSA, Wave 3

Finally, a carer's marital status was also found to be associated with the relationship to the person receiving care, again with certain gender differences (Table 8). The vast majority of men and women who were caring for their spouse/partner were married, as were 79 per cent of both men and women who cared for a parent/parent-in-law. Divorce and widowhood appeared to be more prevalent among female carers, with almost a quarter of women caring for a relative/friend/ neighbour or a child/grandchild being divorced and almost one quarter of women caring for a relative/friend/neighbour being widowed.

Moving beyond the characteristics of carers and the nature of the caring activity, the third section of this article turns to the relationship between caring on one hand, and health status and economic activity patterns on the other. 


\section{Table 8 Relationship to person receiving care by marital status and sex, 2006}

\begin{tabular}{|c|c|c|c|c|c|}
\hline & $\begin{array}{c}\text { Single/never } \\
\text { married }\end{array}$ & $\begin{array}{l}\text { Married/civil } \\
\text { partnership }\end{array}$ & $\begin{array}{l}\text { Divorced/ } \\
\text { seprarated }\end{array}$ & Widowed & $\begin{array}{l}\text { Number in } \\
\text { analysis }\end{array}$ \\
\hline \multicolumn{6}{|l|}{$\operatorname{Men}^{\mathrm{a}}$} \\
\hline Cared for spouse/partner & - & 96.2 & [3.0] & [0.8] & 137 \\
\hline Cared for parent/parent-in-law & 12.2 & 79.3 & [6.1] & [2.4] & 88 \\
\hline Cared for other rel./friend/neighbour & [1.8] & 73.2 & [10.7] & [14.3] & 60 \\
\hline Cared for child/grandchild & [2.3] & 81.4 & [9.3] & [7.0] & 43 \\
\hline \multicolumn{6}{|l|}{ Women $^{\mathrm{b}}$} \\
\hline Cared for spouse/partner & [1.7] & 96.6 & [0.8] & [0.8] & 123 \\
\hline Cared for parent/parent-in-law & [4.3] & 78.7 & 13.3 & [3.7] & 230 \\
\hline Cared for other rel./friend/neighbour & 10.5 & 57.3 & 8.9 & 23.4 & 152 \\
\hline Cared for child/grandchild & & 75.8 & 14.5 & 9.7 & 149 \\
\hline
\end{tabular}
$a: x 2=46.609, d f=9, p<0.001$;
b: $x 2=89.670, d f=9, p<0.001$

Note: Percentages in brackets are based on cell counts below 10.

Source: ELSA, Wave 3

\section{Health status and economic activity patterns of carers}

\section{Health status}

The health status of carers is measured using the two variables of self-reported general health (derived as 'good, 'fair' or 'poor') and the reporting of a limiting longstanding illness (LLSI) (yes/no). The ELSA data present a complicated relationship between health status and the provision of care, particularly when care intensity is taken into account (Table 9). In the first instance, carers appear more likely than non-carers to report good health, and seem less likely than non-carers to report fair or poor health. This pattern is mirrored in the reporting of a LLSI, although these results are not statistically significant. These results are replicated in Waves 1, 2 and 4, and are broadly similar (but not statistically significant) for men and women. Table 9 also shows an inverse relationship between good health and care intensity, with the proportion of carers reporting good health decreasing as the number of hours of care provided increases. The relationship between care intensity and the report of a LLSI is less straightforward, with a lower proportion of round-the-clock carers reporting a LLSI than those caring for 50-167 hours per week. The generally good or fair health status of carers may be due to the nature of care explored in this dataset, which is of a more general kind and also includes childcare, while the relatively good heath status of round-the-clock carers may be considered a prerequisite for providing care round-the-clock. This category's relatively good health status may also be partly due to the fact that the vast majority of round-theclock carers care for their spouse/partner and are married, and marriage is associated with a better health status ${ }^{18}$. 


\section{Table 9 Self-reported health status and report of a LLSI by care intensity, 2006}

\begin{tabular}{|c|c|c|c|c|}
\hline & Good & Fair & Poor & $\begin{array}{r}\text { Number in } \\
\text { analysis }\end{array}$ \\
\hline \multicolumn{5}{|l|}{ Caring $^{\mathrm{a}}$} \\
\hline Yes & 71.4 & 24.0 & 4.6 & 1,000 \\
\hline No & 66.3 & 26.0 & 7.7 & 8,533 \\
\hline \multicolumn{5}{|l|}{ Care intensity ${ }^{b}$} \\
\hline 0-19 hours & 77.8 & 19.1 & 3.2 & 555 \\
\hline $20-49$ hours & 72.1 & 22.1 & 5.9 & 149 \\
\hline $50-167$ hours & 60.6 & 33.3 & {$[6.1]$} & 76 \\
\hline 168 hours (round-the-clock) & 59.4 & 34.7 & 5.9 & 208 \\
\hline Caring $^{c}$ & $\begin{array}{l}\text { With Lim } \\
\text { Standing II }\end{array}$ & $\begin{array}{l}\text { Long } \\
\text { s (LLSI) }\end{array}$ & No LLSI & $\begin{array}{c}\text { Number in } \\
\text { analysis }\end{array}$ \\
\hline Yes & & 53.8 & 46.2 & 1,000 \\
\hline No & & 55.3 & 44.7 & 8,763 \\
\hline \multicolumn{5}{|l|}{ Care intensity $^{d}$} \\
\hline 0-19 hours & & 50.0 & 50.0 & 555 \\
\hline $20-49$ hours & & 47.1 & 52.9 & 149 \\
\hline $50-167$ hours & & 72.7 & 27.3 & 76 \\
\hline 168 hours (round-the-clock) & & 60.9 & 39.1 & 208 \\
\hline
\end{tabular}
a: $x 2=15.129, d f=4, p<0.005$;
$b: x^{2}=28.355, d f=6, p<0.001$;
c: $x 2=1.481, d f=2, p=0.477$;
$d: x 2=18.825, d f=3, p<0.001$

Note: Percentages in brackets are based on cell counts below 10 .

Source: ELSA, Wave 3

\section{Economic activity}

The ELSA data show a statistically significant relationship between economic activity and care provision, as well as between economic activity and the intensity of care provision. Table 10 shows that, among those aged 50-64, carers were less likely to be employed or self-employed than noncarers. However, when we explore economic activity patterns among carers only, and according to the number of hours of care provided, a more complex picture emerges.

\section{Table 10 Economic activity $\mathbf{5 0 - 6 4}$ year olds by care intensity, 2006}

\begin{tabular}{|c|c|c|c|c|c|c|}
\hline & $\begin{array}{c}\text { Employed/Self- } \\
\text { employed }\end{array}$ & Unemployed & $\begin{array}{l}\text { Retired/Semi- } \\
\text { retired }\end{array}$ & $\begin{array}{l}\text { Permanently } \\
\text { sick/disabled }\end{array}$ & $\begin{array}{l}\text { Looking after } \\
\text { home/family }\end{array}$ & $\begin{array}{c}\text { Number in } \\
\text { analysis }\end{array}$ \\
\hline \multicolumn{7}{|l|}{ Caring $^{\mathrm{a}}$} \\
\hline Yes & 50.8 & {$[1.1]$} & 23.2 & 5.1 & 19.8 & 581 \\
\hline No & 64.4 & 1.9 & 18.5 & 9.1 & 6.1 & 4,319 \\
\hline \multicolumn{7}{|l|}{ Care intensity ${ }^{b}$} \\
\hline $0-19$ hours & 62.3 & - & 18.4 & 5.8 & 13.5 & 346 \\
\hline 20-49 hours & 42.9 & [4.4] & 31.9 & {$[2.2]$} & 18.7 & 97 \\
\hline $50-167$ hours & 30.6 & - & 50.0 & [2.8] & [16.7] & 40 \\
\hline 168 hours & & & & & & \\
\hline (round-the-clock) & 23.3 & - & 22.1 & [8.1] & 46.5 & 92 \\
\hline
\end{tabular}

a: $x^{2}=141.291, d f=4, p<0.001 ; \quad$ b: $x^{2}=101.399, d f=12, p<0.001$

Note: Percentages in brackets are based on cell counts below 10.

Source: ELSA, Wave 3 
The proportion of carers who were employed or self-employed decreased as the number of hours of care provided rose, however the proportion of those providing up to 19 hours of care per week who were employed or self-employed was almost similar to the equivalent proportion of non-carers (62 per cent compared to 64 per cent). One of the most striking results of this analysis is that almost one quarter of round-the-clock carers aged 50-64 were employed or self-employed, and additional analysis showed that the majority of those (four fifths) were employed.

Table 11 focuses on the population aged 50-64, distinguishing between those who were engaged in some kind of economic activity (employed, self-employed or unemployed) and those who were not (retired, semi-retired, permanently sick/disabled and those looking after home/family). Two thirds of all non-carers aged 50-64 were economically active, compared with just over half of all carers. This is true for both men and women. For example, 73 per cent of male non-carers were economically active, compared to 57 per cent of male carers. Similarly, 59 per cent of female noncarers were economically active, compared to 49 per cent of female carers.

\section{Table 11 Economic activity $\mathbf{5 0 - 6 4}$ year olds by sex and care intensity, 2006}

\begin{tabular}{|c|c|c|c|}
\hline & Active & Inactive & $\begin{array}{r}\text { Number in } \\
\text { analysis }\end{array}$ \\
\hline \multicolumn{4}{|l|}{ All - Caring ${ }^{a}$} \\
\hline Yes & 51.8 & 48.2 & 581 \\
\hline No & 66.3 & 33.7 & 4,319 \\
\hline \multicolumn{4}{|l|}{ Care intensity $^{b}$} \\
\hline 0-19 hours & 62.5 & 37.5 & 346 \\
\hline $20-49$ hours & 47.8 & 52.2 & 97 \\
\hline $50-167$ hours & 30.6 & 69.4 & 40 \\
\hline 168 hours (round-the-clock) & 23.5 & 76.5 & 92 \\
\hline \multicolumn{4}{|l|}{ Men - Caring ${ }^{c}$} \\
\hline Yes & 56.7 & 43.3 & 174 \\
\hline No & 73.3 & 26.7 & 2,076 \\
\hline \multicolumn{4}{|l|}{ Care intensity $^{d}$} \\
\hline 0-19 hours & 67.3 & 32.7 & 117 \\
\hline $20-49$ hours & [42.9] & 57.1 & 20 \\
\hline $50-167$ hours & [41.7] & {$[58.3]$} & 11 \\
\hline 168 hours (round-the-clock) & [22.7] & 77.3 & 24 \\
\hline \multicolumn{4}{|l|}{ Women - Caring ${ }^{\mathrm{e}}$} \\
\hline Yes & 49.4 & 50.6 & 407 \\
\hline No & 58.8 & 41.2 & 2,243 \\
\hline \multicolumn{4}{|l|}{ Care intensity ${ }^{f}$} \\
\hline 0-19 hours & 59.4 & 40.6 & 229 \\
\hline $20-49$ hours & 49.3 & 50.7 & 77 \\
\hline $50-167$ hours & [29.2] & 70.8 & 29 \\
\hline 168 hours (round-the-clock) & 23.8 & 76.2 & 68 \\
\hline
\end{tabular}
a: $x 2=42.661, d f=1, p<0.001$;
b: $x 2=48.292, d f=3, p<0.001$;
c: $x 2=21.531, d f=1, p<0.001$;
$\mathrm{d}: \mathrm{X} 2=18.199, \mathrm{df}=3, \mathrm{p}<0.001$;
e: $x 2=10.638, d f=1, p<0.005$;
$f: x 2=28.288, d f=3, p<0.001$

Note: Percentages in brackets are based on cell counts below 10.

Source: ELSA, Wave 3 
When the intensity of care provision was taken into account, the prevalence of economic activity decreased as the number of hours of care provided increased. For example, 62 per cent of all carers providing between $0-19$ hours of care were active, compared to 48 per cent of those caring for 20-49 hours, 31 per cent of those caring for 50-167 hours and one quarter of the round-theclock carers. Analysis of the 50-64 year old population by age group (50-54, 55-59 and 60-64), which was not statistically significant and not shown here, showed a decrease in economic activity among both carers and non-carers at key age stages in the life course, namely among women aged 60-64 who enter retirement, and among men aged 60-65 who take early retirement. Certain gender differences are worth noting: Among less intense carers (0-19 hours), 67 per cent of men compared to 59 per cent of women were economically active. Finally, almost half of women caring for 20-49 hours and almost one quarter of female round-the-clock carers were economically active.

\section{What makes a round-the-clock carer?}

The most intriguing results in this article refer to the round-the-clock carers, who constitute just over one fifth of all carers in this wave, are more likely to report good health than less intense carers, are roughly evenly distributed among men and women, and one quarter of whom, among those aged 50-64, are engaged in economic activity. To investigate the relative importance of factors affecting one's chances of caring round-the-clock, the final part of the analysis in this article estimated the odds of being a round-the-clock carer for men and women separately (Table 12). The findings suggest that care-giving over the age of 50 is quite a different experience for men and women. The model was built in six stages, taking age (by 10 year age groups), marital status, health status, the reporting of a LLSI, economic activity and the relationship to the person cared for into account, and it shows that the predictors of being a round-the-clock carer are quite different for men and women. The logistic regression shows that the relationship with the person receiving care is by far the strongest predictor of being a round-the-clock carer for both men and women, with its inclusion resulting in the largest reduction in the log likelihood ratio. Those caring for their spouse/ partner were significantly more likely to be round-the-clock carers than any other group.

When exploring other predictors of being a round-the-clock carer, the gendered nature of care provision over the age of 50 becomes more apparent. For example, age is a stronger predictor for male carers until economic activity is entered in the model, while marital status remains a strong predictor at the variable level for female carers even when economic activity is taken into account. The odds of men aged 70-79 being round-the-clock carers are 4.7 times the odds of men aged 5059 , while the odds of men aged 80 and over being round-the-clock carers are 5 to 7 times the odds of men aged 50-59. This confirms men's increasing likelihood to care in older ages and their greater likelihood to care for their spouse/partner. Age is not a significant predictor for women, perhaps because women are more likely than men to provide care throughout older age and not only in the oldest age group. By contrast, marital status is a much stronger predictor of being a round-the-clock carer among women. For example, the likelihood of being a round-the-clock carer for widowed women was 88 per cent lower than for single, never married women (model 5).

The relationship between health status and round-the-clock care provision remains difficult to interpret from the results. Reporting a LLSI appears to be not significant as a predictor for either men or women, while health status is generally not significant, with one exception. Women who reported 'fair' health were 78 per cent more likely than women reporting 'good' health to be round- 
the-clock carers (model 4), but this effect is not significant, once economic activity and relationship to the person receiving care are controlled for.

Finally, economic activity is a strong predictor for both men and women. For women it was, even when the relationship with the person receiving care, is taken into account. The models show an interesting relationship between employment and round-the-clock care. Employed men and women are between 78-82 per cent less likely than retired/semi-retired men and women to be round-theclock carers (model 5). As we might expect, looking after a home/family made a carer much more likely to be caring round-the-clock, but this effect was greater for men. The odds of men who look after the home/family being round-the-clock carers were eight times those of retired/semi-retired men. The odds of women who look after the home/family of being round-the-clock carers were three times those of retired/semi-retired women. A detailed exploration of the employment patterns of male and female carers, including a breakdown of part- and full-time work, would be necessary to analyse further the relationship between economic activity and intense care provision.

\section{Table 12a Odds ratios of being a round-the-clock carer, men, 2006}

\begin{tabular}{|c|c|c|c|c|c|c|}
\hline & Model 1 & Model 2 & Model 3 & Model 4 & Model 5 & Model 6 \\
\hline \multicolumn{7}{|l|}{ Age group } \\
\hline $50-59$ (ref) & $1.00^{* * *}$ & $1.00^{* * *}$ & $1.00^{* * *}$ & $1.00^{* * *}$ & (ns) & (ns) \\
\hline $60-69$ & 2.18 & 2.18 & 2.11 & 1.99 & & \\
\hline $70-79$ & $5.05^{\star * *}$ & $5.31^{* * *}$ & $5.12^{\star * *}$ & $4.73^{\star * *}$ & & \\
\hline 80 and over & $5.38^{* * *}$ & $7.40^{* * *}$ & $7.11^{* * *}$ & $6.69^{* * *}$ & & \\
\hline \multicolumn{7}{|l|}{ Marital status } \\
\hline Single, never married (ref) & - & (ns) & (ns) & (ns) & (ns) & (ns) \\
\hline Married/civil partnership & & & & & & $0.04^{* *}$ \\
\hline \multicolumn{7}{|l|}{ Divorced/separated } \\
\hline \multicolumn{7}{|l|}{ Widowed } \\
\hline Health status & - & - & (ns) & (ns) & (ns) & (ns) \\
\hline LLSI & - & - & - & (ns) & (ns) & (ns) \\
\hline \multicolumn{7}{|l|}{ Economic activity } \\
\hline Retired/semi-retired (ref) & - & - & - & - & $1.00^{* * *}$ & (ns) \\
\hline Employed & & & & & $0.18^{* * *}$ & \\
\hline Self-employed & & & & & 0.16 & \\
\hline Permanently sick/disabled & & & & & 0.96 & \\
\hline Looking after home/family & & & & & $7.98^{* * *}$ & \\
\hline \multicolumn{7}{|c|}{ Relationship to person receiving care } \\
\hline Spouse/partner (ref) & - & - & - & - & - & $1.00^{* * *}$ \\
\hline Parent/parent-in-law & & & & & & $0.02^{* \star *}$ \\
\hline Other relative/friend/neighbour & & & & & & $0.02^{* * *}$ \\
\hline Child/grandchild & & & & & & $0.17^{\star \star *}$ \\
\hline Constant & $0.007^{* * *}$ & $0.005^{* * *}$ & $0.005^{\star * *}$ & $0.007^{* * *}$ & $0.012^{* * *}$ & 21.053 \\
\hline Log Likelihood ratio & 719.4 & 700.7 & 694.2 & 687.8 & 649.9 & 223.7 \\
\hline \multicolumn{7}{|l|}{${ }^{*} p<0.010$} \\
\hline \multicolumn{7}{|l|}{${ }^{* *} p<0.005$} \\
\hline \multicolumn{7}{|l|}{${ }^{* * *} p<0.001$} \\
\hline \multicolumn{7}{|l|}{$(n s)=$ not significant. } \\
\hline a Note: 'Unemployed' was exclu & models & there $w$ & no unem & ved amo & & -clo \\
\hline
\end{tabular}


These results confirm the gendered pathways of men and women into care provision in later life. Round-the-clock caring by women is largely determined by who they care for, but also by their marital and economic activity status. Earlier in this article we saw that women provide more care in every age group, and, if round-the-clock carers, in about half of the cases they look after a parent/ parent-in-law or a child/grandchild. For men it is the relationship to the person they care for, as well as their age and economic activity status which determine whether they will become round-theclock carers. Indeed, for the majority of men, intense care provision is an experience which comes in older ages, and which is predominantly focused on their spouse/ partner.

\section{Table 12b Odds ratios of being a round-the-clock carer, women, 2006}

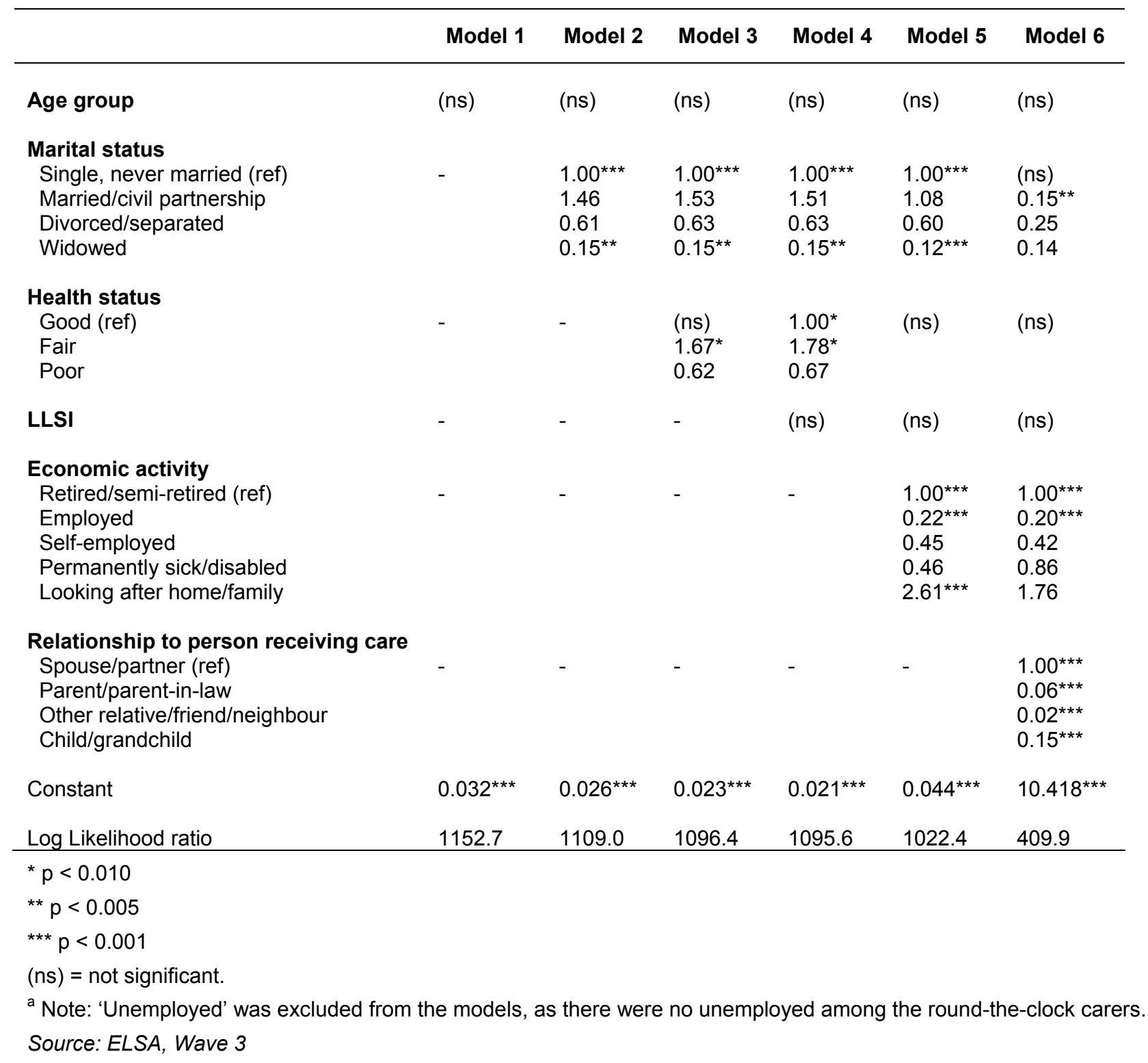




\section{Discussion}

Some of the results presented in this article are in line with existing research on informal care provision in older ages, while other findings raise additional policy-relevant questions which require further investigation. The results suggest that women are more likely than men to provide care overall and more likely to care across all age groups, except among the oldest old. Women also appear more likely than men to be combining different caring roles and to be caring for more than one person; however, men are more likely than women to be caring for their spouses/partners.

The results of this article suggest the relationship between the provision of care and health status over the age of 50 is more difficult to assess. The greater likelihood among carers to report good health -compared to non-carers- may be explained by the fact that a certain level of good health is necessary in order to be able to care for another person. The prevalence of a good health status appears to be declining as care intensity increases; however, round-the-clock carers seem to report better health than some of the less intense carers. The area of health status in the latter part of the life course is as dynamic as the provision of care. For example, an older person may have been providing care to their grandchild in 2002, but by 2006 they may be receiving care from their children and providing support within the household to their spouse. Further research could investigate the relationship between care provision and health status, but also care receipt and health status, over time, using the ELSA dataset for longitudinal analysis.

It was found that round-the-clock carers constituted more than one fifth of all carers aged 50 and over, and that, compared to carers who provide care for less than 168 hours per week, round-theclock carers are far less likely to be engaged in economic activity, but more likely than less intense carers to report a good health status. The logistic regression results further confirmed that care provision by people aged 50 and over is a profoundly gendered experience, as the determinants of being a round-the-clock carer differ for men and for women, except for the effect of the relationship to the person receiving care. Further research could investigate the factors that affect the chances of being a round-the-clock carer in greater depth and, more crucially, over time. Understanding the socio-economic position of carers better can contribute to additional policy-relevant mechanisms of recognising and supporting carers, particularly of those caring round-the-clock.

\section{Key Findings}

- Women were more likely to care than men, and 'younger old' people (50-64) more likely to care than 'older old' people (65 and over).

- Over half of all carers provided up to 19 hours of care per week, and just over one fifth provided round-the-clock care (168 hours). Men were more likely than women to care for up to 19 hours, and less likely to care between 20-49 hours.

- Men and women were equally likely to care round-the-clock, and the majority of these carers looked after their spouse/partner. However, women were more likely to be round-the-clock carers at a younger age and to be looking after parents/parents-in-law or children/grandchildren, while men were more likely to be round-the-clock carers at older ages and to be 


\section{Key Findings}

looking after their spouse/partner.

- Patterns of care provision varied across old age and in different ways for men and women. Women were more likely than men to care across their older ages, more likely to care for longer hours, and more likely to care for all categories of care recipients except for spouses/partners. Men were more likely to care in older ages and for their spouse/partner.

- More than three quarters of carers were married, and two fifths of all carers lived with the person receiving care.

- Carers appeared to be more likely than non-carers to report good health and not to report a limiting longstanding illness, but health status deteriorated as care intensity rose. The exception was round-the-clock carers, who reported better health status than some of the less intense carers.

- Men aged 50-64 were more likely to be economically active than women, both among carers and non-carers. Economically active persons were less likely to provide care compared to economically inactive persons, and the prevalence of economic activity decreased as care intensity rose. However, one quarter of round-the-clock carers in this age group were economically active, and the majority of these were employed.

- The strongest predictors of being a round-the-clock carer for both men and women are the relationship to the person they care for and their economic activity status. Among women, marital status also remains an important determinant, while age appears to be a more important determinant for men.

\section{Acknowledgements}

The author wishes to thank Maria Evandrou, Jane Falkingham and the anonymous referees for their useful comments on earlier drafts of this article. All responsibility for the analysis and interpretation of the data rests with the author.

\section{References}

1 Office for National Statistics (2003) Census 2001: Key Statistics for local authorities in England and Wales. London, The Stationery Office.

2 Maher, J and Green, H (2002) Carers 2000. London: The Stationery Office.

3 See for example: Evandrou, M and Glaser, K (2003) 'Combining work and family life: the pension penalty of caring'. Ageing and Society 23 (5) 583-602. 
4 Arber, S (2006) 'Gender and Later Life: Change, Choice and Constraints'. In: Vincent, JA, Phillipson, CR and Downs, M :The Futures of Old Age. London: Sage and the BSG. Pp 54-61.

5 National Population Projections, 2008-based (2009) Office for National Statistics, Statistical Bulletin. Available at: www.statistics.gov.uk/statbase/Product.asp?vlnk=8519

6 Pickard, L, Wittenberg, R, Comas-Herrera, A, Davies, B and Darton, R (2000) 'Relying on informal care in the 21st century? Informal care for elderly people in England to 2031'. Ageing and Society 20: 745-772.

7 See for example: Arber, S and Ginn, J (1990) 'The Meaning of Informal Care: Gender and the Contribution of Elderly People'. Ageing and Society 10: 429-454.

8 Dahlberg, L Demack, S and Bambra, C (2007) 'Age and gender of Informal Carers: A Population-based Study in the UK'. Health and Social Care in the Community 5: 439-445.

9 Office for National Statistics (2006) Focus on Health. 2006 Edition. Basingstoke: Palgrave Macmillan. Available at: www.statistics.gov.uk/statbase/Product.asp?vlnk=12985

10 See for example: Arber, S and Ginn, J (1995) 'Gender Differences in Informal Care'. Health and Social Care in the Community 3: 19-31.

11 Glaser, K and Grundy, E (2002) 'Class, caring and disability: evidence from the British Retirement Study'. Ageing and Society 22: 325-342.

12 Hyde, M and Janovic, M (2004). 'Social activity'. In: Marmot, M et al. (eds) Health, wealth and lifestyles of the older population in England. The 2002 English Longitudinal Study of Ageing. London: The Institute for Fiscal Studies. Pages 167-179.

13 Evandrou, M and Glaser, K (2004) 'Family, work and quality of life: Changing economic and social roles through the lifecourse'. Ageing and Society 24 (1) 1-21.

14 Buckner, LJ and Yeandle, SM (2007) Valuing Carers: Calculating the Value of Unpaid Care, Research Report Prepared for Carers UK. London: Carers UK.

15 ELSA Technical Reports (Waves 1,2,3 and 4 - Phase 1). Available from the Economic and Social Data Service: www.esds.ac.uk

16 Del Bono, E, Sala, E and Hancock, R (2009) 'Older carers in the UK: are there really gender differences? New analysis of the Individual Sample of Anonymised Records from the 2001 UK Census'. Health and Social Care in the Community 17 (3) 267-273.

17 Young, H, Grundy, E and Jitlal, M. (2006) Care Providers, Care Recievers. A Longitudinal Perspective. York: Joseph Rowntree Foundation.

18 More than 70 per cent of all married persons in Wave 3 reported good health, compared to 60 per cent of non-married persons, and conversely, six per cent of all married persons reported poor health, compared to 10 per cent of non-married persons $(p<0.001)$. 